\section{Union steps up lab safety campaign}

UNION action at UK university and public health laboratories which use dangerous pathogens is to be stepped up in further attempts to improve safety. The Association of Scientific Technical and Managerial Staffs (ASTMS) has warned that it is now to launch a campaign to enforce greater safety at laboratories dealing with category B pathogens-such as those responsible for botulism, typhoid, paratyphoid and the plague. These are organisms less deadly than the category A smallpox virus which caused the death of medical photographer Janet Parker at Birmingham University last year but they still pose special hazards for workers.

The general secretary of ASTMS, Mr Clive Jenkins, said last week that the union would be telling its members: "Do it cleanly. Do it safely. Wear masks when necessary. Use the autoclaves. Use the fume cupboards. Demand things be made safe from the beginning". And he added: "We still have a situation in about $60 \%$ of our laboratories where mouth-pipetting is still permitted. That is disgraceful, awful. We will certainly be urging our members to stop mouth-pipetting at these category $\mathbf{B}$ laboratories.

"I think heads of departments are being dirty, careless and slovenly. There is no excuse for doing things incompetently, inefficiently and in a dirty fashion".

Mr Jenkins said the Birmingham smallpox outbreak and the subsequent revelations of the Shooter report had spurred ASTMS to take a fresh look at the 29,000 people in the laboratory population of universities and the health service. "These people are being ravaged by disease and are contracting all sorts of things like brucellosis, psittacosis, beryllium contamination, TB, hepatitis, and about eight or nine other things as well", he added.

The union now has 2,000 legal cases pending on behalf of its members-of which about $60 \%$ are related to diseases with industrial or laboratory sources. More staff have been taken on to help cope with this load and ASTMS has also rejigged its entire legal department to be investigative rather than retaliatory, Mr Jenkins added. "Our members are flooding us with calls now they realise that we are passionately interested in this area", he claimed.

ASTMS is now negotiatirg a new pay package for its technicians and is expecting a $9 \%$ rise backdated to last

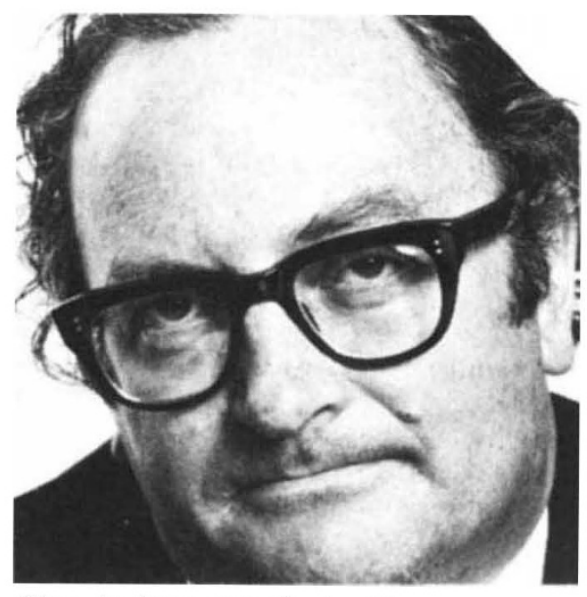

Clive Jenkins: mouth pipetting

"is disgraceful"

October which is to be followed by three other increases over the next 18 months. But Mr Jenkins stressed that although this claim had led to several disputes at departments, the union was trying to rein in its members. "One can damage a university without having any effect at all upon politicians or upon the economy and therefore we feel guilty because in the private sector we have been getting quite sensible agreements. But the universities are a real problem for us".

"We want to abolish the concept of danger money", Mr Jenkins said. "The arguments that we would use are that this is a very hard-working, productive, active and well-qualified group. Discussions about disease are separate. University technicians should be properly rewarded for their qualifications and work but we are not going to be bought off for more money to have them working in slovenly laboratories".

At the same time, ASTMS is still pressing for a public inquiry into the Birmingham outbreak with a legally qualified chairman and some form of union representation. Indeed this latter approach is a particularly important one for the union which wants far greater union representation on all bodies administering laboratories.

And $\mathrm{Mr}$ Jenkins reacted bitterly to the suggestion reported in Nature (29 March, p. 387) of Mark Carlisle, Conservative education and science spokesman, that there should be no lay or union members on the Dangerous Pathogens Advisory Group, the body responsible for screening biological laboratories such as the one at Birmingham.

"I would have thought that that was a scandalously reactionary suggestion. DPAG has been a disaster. We want it disbanded. Everyone inside it should be sacked and the body reconstituted within the Health and Safety Executive. I don't know why he wants the Tories to be the party of germs and danger".

\section{UK taxonomy is healthy, says report}

A REVIEW group of the UK Advisory Board for the Research Councils (ABRC) has recommended that the major support in Britain for taxonomy -the classification of plants and animals-should go to studies of organisms of economic and social importance. Most in need of study it says, are the nematodes, tiny and prolific worms that attack crops and livestock throughout the world. This reflects the concern of the European Science Foundation Group on Biological Recording, Systematics and Taxonomy. which in 1977 instituted a survey of European plant-parasitic nematodes.

The classification of plants and animals may not be one of the more glamorous branches of biology, but the accurate identification of species, both past and present, and the study of their relationships is basic to both fundamental and applied biological progress. Reawakened interest in the field has inspired the official ABRC report, Taxonomy in Britain (HMSO, £3.50). The report has been produced by the ABRC's Review Group on Taxonomy, set up in 1974 under the chairmanship of Sir Eric Smith, formerly director of the Laboratory of the Marine Biological Association of the United Kingdom.

The state of British taxonomy seems on the whole to be healthy, the report concludes, although the group would like to see some changes, particularly to ensure proper care and use of the scattered national collections of biological specimens, and to encourage young people to take up taxonomy.

Also, the British collections of living material including, as well as the plants in the botanic gardens, cultures of algae, protozoa, yeast, bacteria, fungi and viruses, have special needs not shared by dried specimens. The report expresses particular concern about uncertainties in the funding of the collection of living fungi at the Commonwealth Mycological Institute and of the National Collection of Yeast Cultures and recommends that the $A B R C$ review the funding of all such taxonomic reference collections.

To encourage recruitment and training of taxonomists, the report recommends that the study of taxonomy should be fostered as part of the general educational exposure to science and natural history. Field courses are vital, says the report. To build on these foundations there should be a modest increase in the small number of postgraduate studentships for taxonomic research. 